\title{
INSTRUMEN EKONOMI, COMMAND AND CONTROL, DAN INSTRUMEN LAINNYA: KAWAN ATAU LAWAN? SUATU TINJAUAN BERDASARKAN SMART REGULATION
ECONOMIC INSTRUMENTS, COMMAND AND CONTROL, AND
OTHER INSTRUMENTS: FRIENDS OR FOES? COMMENTS FROM A SMART REGULATION PERSPECTIVE

\author{
Andri G. Wibisana ${ }^{a}$
}

\begin{abstract}
ABSTRAK
$\mathrm{D}$ alam konteks konteks penaatan hukum lingkungan, pendekatan Command and Control (CAC, Atur dan Awasi) merupakan pendekatan yang paling sering digunakan sekaligus dikritik. Tulisan ini bermaksud mempertanyakan ulang pandangan yang menempatkan CAC bukan hanya dalam posisi berlawanan dengan instrumen non-CAC, tetapi juga merupakan instrumen/pendekatan yang lebih inferior dibandingkan dengan instrumen non-CAC. Tulisan ini memperlihatkan bahwa selain instrumen CAC, dapat pula diterapkan instrumen ekonomi, instrumen atur diri sendiri (ADS, selfregulation), instrumen sukarela (voluntarism), serta instrumen pendidikan dan informasi. Berangkat dari teori Smart Regulation yang dikembangkan oleh Gunningham et al., tulisan ini berpandangan bahwa yang perlu dilakukan bukan lah upaya mencari alternatif instrumen terbaik, karena setiap instrumen memiliki kelebihan dan kekurangannya masing-masing. Sebaliknya, yang perlu dilakukan adalah menemukan kombinasi optimal di antara berbagai instrumen tersebut, dengan melibatkan keikutsertaan pemerinah, masyarakat, dan publik, dalam penciptaan penaatan lingkungan.
\end{abstract}

Kata kunci: CAC, instrumen ekonomi, smart regulation, penaatan lingkungan.

\begin{abstract}
The Command and Control approach (CAC) is probably the most heavily used and criticized instrument of 1 environmental compliance. This paper questions the view that places the CAC instrument not only in a dichotomy position with the non-CAC instruments but is also inferior compared to non-CAC instruments. This paper shows that in addition to the CAC instrument, economic instruments, self-regulation instruments (selfregulation), voluntary instruments, and educational and information instruments are also likely to be applicable. Departing from the Smart Regulation theory developed by Gunningham et al., this paper is of the view that, given advantages and disadvantages of each instrument, what needed is not an attempt to find the best instrument. Instead, what one needs is to find the optimal combination among these various instruments, by involving the government, community, and the public in the creation of environmental compliance.
\end{abstract}

Keywords: CAC, economic instruments, smart regulation, environmental compliance.

\footnotetext{
a Fakultas Hukum Universitas Indonesia, Jl. Prof. Mr Djokosoetono Depok 16424, email: andri.gunawan@ui.ac.id.
} 


\section{PENDAHULUAN}

Dendekatan yang paling sering digunakan untuk mencapai penaatan lingkungan adalah 1 Atur dan Awasi (ADA), atau dikenal juga dengan Command And Control (CAC) atau direct regulation. ${ }^{1}$ Pendekatan CAC mengindikasikan adanya aturan pemerintah yang menentukan bagaimana masyarakat harus bertindak. Penaatan terhadap aturan ini diciptakan melalui adanya (ancaman) sanksi yang diletakkan pada bagian akhir dari proses CAC. ${ }^{2}$

Pendekatan CAC memperoleh berbagai kritik di Indonesia. Berdasarkan kritik tersebut, akademisi dan pemerintah berupaya untuk memperkenalkan berbagai instrumen inovatif sebagai alternatif atas instrumen/pendekatan CAC. Dari pemikiran ini tersirat adanya dikotomi di antara berbagai instrumen penaatan lingkungan. Pada satu sisi, penaatan didasarkan pada instrumen CAC. Pada sisi lain, penaatan didasarkan pada pendekatan nonCAC melalui berbagai instrumen, seperti instrumen ekonomi, self-regulation, atau bahkan Program Penilaian Peringkat Kinerja Perusahaan dalam Pengelolaan Lingkungan Hidup (PROPER). Instrumen berdasarkan pendekatan non-CAC dianggap merupakan pendekatan alternatif yang lebih baik dalam menciptakan ketaatan warga masyarakat. Di dalam UU Nomor 32 tahun 2009 (UUPPLH), ${ }^{3}$ pendekatan non-CAC ini diberi nama instrumen ekonomi, yang diatur dalam pasal 42 dan 43.

Tulisan ini bermaksud mempertanyakan ulang pandangan yang menempatkan CAC bukan hanya dalam posisi berlawanan dengan instrumen non-CAC, tetapi juga merupakan instrumen/pendekatan yang inferior dibandingkan, dan karenanya harus diganti, dengan instrumen non-CAC. Tulisan ini melihat bahwa pemahaman di atas berangkat dari asumsi yang meragukan yaitu bahwa ada satu instrumen yang inferior dibandingkan dengan instrumen lainnya. Sebaliknya, tulisan ini menyepakati pandangan dari Gunningham et al. yang menyatakan bahwa setiap instrumen penataatan memiliki kekurangan dan kelebihannya masing-masing, sehingga instrumen tersebut dapat diterapkan bersama-sama dan saling melengkapi kekurangan masing-masing. ${ }^{4}$

Tulisan ini menganalisis instrumen penaatan dengan menggunakan kerangka berpikir smart regulation, sebagaimana dikembangkan oleh Gunningham et al. di dalam bukunya: Smart

1 Untuk selanjutnya, tulisan ini akan menggunakan istilah CAC.

2 Lihat, misalnya, penjelasan dari: Michiel A. Heldeweg dan René J.G.H. Seerden, Environmental Law in the Netherlands (Alphen aan de Rijn: Wolters Kluwer, 2012, hlm. 48.

3 UU Nomor 32 Tahun 2009 tentang Perlindungan dan Pengelolaan Lingkungan Hidup, LN Tahun 2009 Nomor 140, TLN Nomor 5059 (selanjutnya disebut UUPPLH).

4 Neil Gunningham dan Darren Sinclair, "Regulatory Pluralism: Designing Policy Mixes for Environmental Protection", Law \& Policy, Vol. 21:1 (1999a), hlm. 50. 
Regulation: Designing Environmental Policy. ${ }^{5}$ Menurut Gunningham, regulasi yang cerdas merujuk pada pluralisme pengaturan (regulatory pluralism), sebagai bentuk kontrol sosial yang fleksibel, imaginatif, dan inovatif. Bentuk pluralisme di sini diartikan sebagai keterlibatan pemerintah, pelaku usaha, dan masyarakat (pihak ketiga) dalam penyusunan dan penerapan norma. Dalam konteks ini, berbeda dari regulasi yang hanya menitikberatkan pada keterkaitan dua pihak, yaitu pemerintah sebagai pihak regulator dan pelaku usaha sebagai pihak yang diatur (regulated communities), maka smart regulation didasarkan pada pemikiran bahwa berbagai pihak dapat mempengaruhi perilaku regulated communities, baik secara formal maupun informal. 6 Smart regulation tidak hanya melihat keterkaitan dan kombinasi antara satu instrumen penaatan dengan instrumen lainnya, tetapi juga menjelaskan keterlibatan pemerintah, pelaku usaha, dan masyarakat (baik komersial maupun non-komersial) dalam penerapan instrumen-instrumen tersebut.7

Setelah Pendahuluan (Bagian A), Bagian B menunjukkan bagaimana CAC diterapkan dan dikritik di Indonesia. Kritik tersebut sejalan dengan munculnya pengelompokkan instrumen penaatan menjadi dua, yaitu CAC dan instrumen ekonomi. Dikotomi ini dianut oleh UUPPLH dan PP Instrumen Ekonomi. ${ }^{8}$ Bagian C menguraikan dasar bantahan terhadap dikotomi instrumen penaatan. Dalam Bagian ini dipaparkan perkembangan instrumen

5 Neil Gunningham, Peter Grabosky, dan Darren Sinclair, 2004, Smart Regulation: Designing Environmental Policy Oxford: Oxford University Press

6 Neil Gunningham, "Enforcement and Compliance Strategies", dalam: Robert Baldwin, Martin Cave, and Martin Lodge (eds.), The Oxford Handbook of Regulation, Sep 2010, DOI:10.1093/oxfordhb/9780199560219.003.0007, hlm. 131.

7 Pengertian atas smart regulation yang digunakan dalam tuisan ini mungkin saja berbeda dari pengertian yang dianut oleh pengarang lain di Indonesia. Riyanto, misalnya, justru sepertinya mengartikan smart regulation sebagai sebuah pendekatan yang berlawanan dengan pendekatan CAC. Dalam tulisannya mengenai kebijakan kehutanan di Indonesia, Riyanto mengkritik kebijakan yang ada selama ini, yang dinilainya sebagai kebijakan yang masih "bernuansa command and control. Sehingga dianggap tidak memacu dunia investasi dan tidak pro-poor". Lihat: Budi Riyanto, 2005, Hukum Kehutanan dan Sumber Daya Alam: Menuju Smart Regulation (Bogor: Lembaga Pengkajian Hukum Kehutanan dan Lingkungan, hlm. 12.

Setelah mengkritik pendekatan CAC di dalam sektor kehutanan, Riyanto mengusulkan agar pola pikir kebijakan harus lah bergeser "dari pemikiran command and control menuju pengaturan yang bijak atau smart regulation." Ibid., hlm. 15. Menurut Riyanto, smart regulation dalam sektor kehutanan adalah peraturan yang memiliki ciri-ciri: adanya swakelola hutan, adanya insentif dan disinsentif, desentralisasi, adanya penilaian kinerja yang didasarlkan pada hasil dan bukan pada kepatuhan, adanya pemanfaatan mekanisme pasar, adanya kemampuan untuk mengantisipasi masalah publik agar mampu melakukan tindakan preventif, adanya pengelolaan hutan yang berorientasi pada pemberdayaan dan peran serta masyarakat. Ibid., hlm. 14. Dari uraian di atas, smart regulation menurut Riyanto sepertinya memang sudah meninggalkan pendekatan CAC sama sekali.

Uraian Riyanto mengenai smart regulation perlu lah diapresiasi sebagai sebuah upaya awal memperkenalkan smart regulation dalam kebijakan lingkungan hidup di Indonesia. Namun demikian, pandangan tersebut perlu ditanggapi karena dua alasan. Pada satu sisi, pandangan Riyanto mengenai smart regulation tidak didukung oleh literatur yang selama ini dikenal terkait smart regulation. Pada sisi lain, upaya meninggalkan pendekatan CAC tidak sejalan dengan smart regulation. Seperti akan dijelaskan dalam tulisan ini, smart regulation justru melihat bahwa pendekatan CAC tidaklah sepenuhnya dapat ditinggalkan.

8 PP Nomor 46 tahun 2017 tentang Instrumen Ekonomi Lingkungan Hidup, LN 2017 Nomor 228, TLN Nomor 6134 [PP Instrumen Ekonomi]. 
Instrumen Ekonomi, Command and Control, dan Instrumen Lainnya: Kawan atau Lawan?

ekonomi menjadi empat tahap, yaitu: CAC, instrumen ekonomi, hukum refleksif, serta pendekatan integratif dan multimoda. Bagian D akan menguraikan secara singkat berbagai instrumen penaatan. Bagian E menjelaskan secara singkat berbagai kemungkinan kombinasi instrumen (policy mixes). Bagian F akan menguraikan kesimpulan.

\section{PEMBAHASAN}

\section{CAC dan Instrumen Ekonomi: Dikotomi Instrumen Penaatan Lingkungan di Indonesia}

Dendekatan CAC dapat dijelaskan di dalam pola yang lazim disebut sebagai "rantai 1 regulasi". Menurut pola ini, rantai regulasi dimulai dari perencanaan, yang bertujuan untuk mencari dasar dari regulasi. Termasuk ke dalam perencanaan ini adalah penentuan persoalan yang hendak dihadapi, prioritas pilihan yang dimiliki, kemungkinan solusi atas persoalan, serta target yang hendak dicapai. Berdasarkan rencana ini disusun lah produk legislasi yang baru atau yang mengubah produk lama. Produk legislasi ini diturunkan ke dalam berbagai peraturan pelaksanaan, yang dapat berisi berbagai bentuk standar, kewajiban, persyaratan usaha/kegiatan, atau aturan-aturan implementatif lainnya. Selanjutnya, regulasi yang bersifat umum tersebut akan diterjemahkan ke dalam berbagai perizinan yang sifatnya konkret dan individual. Pemerintah kemudian melakukan pengawasan pelaksanaan izin, terutama terkait ketaatan terhadap kewajiban menurut peraturan perundang-undangan dan izin. Selanjutnya, pemerintah akan menjatuhkan sanksi terhadap pelanggaran atau ketidaktaatan. ${ }^{9}$

Instrumen penaatan yang dilahirkan dari pendekatan CAC dapat diterangkan berdasarkan derajat campur tangan pemerintah sebagaimana diuraikan oleh Ogus. Campur tangan tersebut terdiri atas beberapa bentuk, mulai dari campur tangan yang paling ringan (yaitu regulasi informasi), campur tangan sedang (yaitu bentuk standar/baku mutu), dan campur tangan paling intervensionis (yaitu perizinan). ${ }^{10}$

Contoh dari campur tangan tersebut dapat pula ditemukan di dalam UUPPLH. ${ }^{11}$ Untuk regulasi atas informasi (information regulation), contoh instrumennya dapat ditemukan dalam kewajiban penyediaan informasi lingkungan,12 serta larangan pemberian informasi tidak benar

\footnotetext{
9 Lihat: Michiel A. Heldeweg dan René J.G.H. Seerden, Op. Cit., hlm. 48-49.

10 Anthony Ogus, 2004, Regulation: Legal Form and Economic Theory, Oxford: Clarendon Press, hlm. 151.

11 Untuk diskusi lebih lanjut mengenai berbagai instrumen CAC berdasarkan derajat campur tangan pemerintah, lihat misalnya: Andri G. Wibisana, 2017, “Campur Tangan Pemerintah dalam Pengelolaan Lingkungan: Sebuah Penelusuran Teoretis Berdasarkan Analisis Ekonomi atas Hukum (Economic Analysis of Law)", Jurnal Hukum E Pembangunan, Vol. 47:2, hlm. 162-177.

12 UUPPLH, Pasal 68.
} 
terkait pengelolaan lingkungan dan ancaman pidana bagi mereka yang memberikan informasi tidak benar tersebut. ${ }^{13}$ Termasuk ke dalam instrumen baku mutu (stardards) adalah berbagai bentuk baku mutu lingkungan dan kriteria baku kerusakan lingkungan. ${ }^{14}$ Sedangkan untuk sistem perizinan (prior approval), dapat ditemukan dalam perangkat izin lingkungan beserta persyaratannya. ${ }^{15}$

Kritik terhadap CAC dapat dilihat dari pandangan Soemarwoto. Menurutnya, pendekatan CAC gagal mencapai hasil yang memuaskan karena pendekatan ini memiliki beberapa kelemahan. Pertama, CAC terlalu mendasarkan diri pada pandangan bahwa perilaku anti-lingkungan dapat dilawan dengan peraturan perundang-undangan. Pandangan ini bertentangan dengan sifat egoisme manusia yang selalu mencari tindakan yang menguntungkan dirinya; sehingga ketika dihadapkan pada peraturan perundang-undangan, manusia sering kali secara diam-diam melakukan pelanggaran. ${ }^{16} \mathrm{Kedua}$, CAC bersifat top-down dan instruktif, di mana masyarakat diharuskan melaksanakan apa yang tertulis di dalam peraturan perundang-undangan menurut interpretasi dari Pemerintah. Di dalam CAC, masyarakat dan industri tidak didorong dan tidak diberikan insentif untuk berperilaku ramah lingkungan. ${ }^{17}$ Ketiga, CAC bersifat kaku dan birokratis. Dalam konteks ini, aturan dibuat secara rinci dan detail, dimulai dari undang-undang sampai pada tingkat petunjuk pelaksanaan dan petunjuk teknis. Kekakuan ini, berakibat pada tidak berkembangnya teknologi dan sistem pengelolaan lingkungan. Selain itu, kekakuan CAC menjadikan pendekatan ini sangat birokratis, sehingga pejabat sering kali bertindak lebih demi kepentingan birokrasi dari pada demi perbaikan kondisi lingkungan. ${ }^{18}$

${ }^{13}$ UUPPLH, Pasal 69, jo. Pasal 113.

14 UUPPLH, Pasal 20 dan 21.

15 UUPPLH, Pasal 36-41.

${ }^{16}$ Otto Soemarwoto, 2001, Atur Diri Sendiri: Paradigma Baru Pengelolaan Lingkungan Hidup. Pembangunan Ramah Lingkungan: Berpihak pada Rakyat, Ekonomis, dan Berkelanjutan, Gajah Mada University Press, hlm. 98.

17 Ibid., hlm. 99.

18 Ibid., hlm. 100-105.

Kritik terhadap CAC dapat pula ditemukan di dalam terbitan resmi Kementerian LH terkait PROPER. Di dalam publikasi tersebut, Reliantoro menyatakan bahwa "pendekatan pengelolaan lingkungan konvensional "command and control" ternyata tidak dapat mendorong peningkatan kinerja pengelolaan lingkungan perusahaan secara menyeluruh." Hal ini terjadi, menurut Reliantoro, karena CAC mensyaratkan adanya kemampuan pemerintah untuk memastikan bahwa seluruh entitas yang diatur taat terhadap peraturan yang ditetapkan. Pada saat pengawasan lemah ketidaktaatan akan meningkat, sehingga pelaku usaha/kegiatan menjadi "merasa bebas untuk berbuat sembarangan dan melanggar peraturan". Mengingat keterbatasan pengawasan ini, Reliantoro berpandangan bahwa pengawasan perlu beralih dari pengawasan oleh pemerintah menjadi pengawasan oleh pasar dan masyarakat. Menurutnya, "[j]ika proses pengawasan-penegakan hukum formal memerlukan waktu dan biaya yang besar bagi kedua belah pihak, di mana kedua belah pihak harus saling berkonfrontasi untuk membuktikan argumentasi masing-masing, maka pengawasan oleh masyarakat dan pasar bermain dengan lebih halus dan sesuai dengan sifat-sifat dasar manusia." Atas dasar keunggulan dari pengawasan oleh masyarakat dan pasar inilah PROPER dikembangkan. Lihat: Lihat: Sigit Reliantoro, The Gold for Green: Bagaimana Penghargaan 
Instrumen Ekonomi, Command and Control, dan Instrumen Lainnya: Kawan atau Lawan?

UUPPLH tidak secara tegas menjelaskan jenis-jenis pendekatan penaatan yang dianutnya. Akan tetapi di dalam Penjelasan Umum tertulis bahwa:19

“Upaya preventif dalam rangka pengendalian dampak lingkungan hidup perlu dilaksanakan dengan mendayagunakan secara maksimal instrumen pengawasan dan perizinan. Dalam hal pencemaran dan kerusakan lingkungan hidup sudah terjadi, perlu dilakukan upaya represif berupa penegakan hukum yang efektif, konsekuen, dan konsisten terhadap pencemaran dan kerusakan lingkungan hidup yang sudah terjadi.... “Undang-Undang ini juga mendayagunakan berbagai ketentuan hukum, baik hukum administrasi, hukum perdata, maupun hukum pidana. Ketentuan hukum perdata meliputi penyelesaian sengketa lingkungan hidup di luar pengadilan dan di dalam pengadilan....

“Penegakan hukum pidana lingkungan tetap memperhatikan asas ultimum remedium yang mewajibkan penerapan penegakan hukum pidana sebagai upaya terakhir setelah penerapan penegakan hukum administrasi dianggap tidak berhasil."

Dari uraian di atas terlihat bahwa UUPPLH membedakan antara upaya yang bersifat preventif dan upaya represif. Pengawasan dan Perizinan dianggap sebagai upaya preventif, yang dilakukan sebelum pencemaran dan kerusakan lingkungan terjadi. 20 Sedangkan penegakan hukum dianggap merupakan upaya represif yang dilakukan apabila pencemaran/kerusakan tersebut telah terjadi.

UUPPLH mendefinisikan instrumen ekonomi sebagai “seperangkat kebijakan ekonomi untuk mendorong Pemerintah, pemerintah daerah, atau setiap orang ke arah pelestarian fungsi lingkungan hidup" ${ }^{21}$ Oleh Penjelasan Umum UUPPLH, instrumen ekonomi ini digolongkan sebagai instrumen pencegahan pencemaran.22 Adapun perangkat dari instrumen ekonomi ini

PROPER Emas Mendorong Lima Perusahaan Mencapai Inovasi, Penciptaan Nilai dan Keunggulan Lingkungan (Jakarta: Kementerian Lingkungan Hidup, 2012), hlm. 6-9.

Berdasarkan penjelasan di atas, PROPER dianggap menawarkan alternatif kontrol, dari yang di dalam CAC dilakukan oleh pemerintah, menjadi kontrol oleh masyarakat dan pasar. Menurut penjelasan tersebut, dengan dibukanya informasi mengenai kinerja lingkungan dari usaha/kegiatan, maka PROPER dapat mendorong penaatan melalui tekanan respons dari masyarakat dan pasar atas reputasi usaha/kegiatan yang diketahui dari PROPER.

19 UUPPLH, Penjelasan Umum, Paragraf 5.

${ }^{20}$ Dalam hal ini, UUPPLH menguraikan berbagai instrumen pencegahan pencemaran/kerusakan, yang terdiri atas: a). KLHS; b). tata ruang; c). baku mutu lingkungan; d). kriteria baku kerusakan lingkungan; e). amdal; f). UKLUPL; g). perizinan; h). instrumen ekonomi; i). peraturan perundang-undangan berbasis lingkungan hidup; j). anggaran berbasis lingkungan hidup; k). analisis risiko; l). audit lingkungan; dan m). instrumen lain sesuai dengan kebutuhan dan/atau perkembangan ilmu pengetahuan. Lihat: UUPPLH, Pasal 14.

21 UUPPLH, Pasal 1 angka 33.

${ }_{22}$ UUPPLH, Pasal 14 dan Penjelasan Umum, Paragraf 8 huruf d. 
dijelaskan lebih lanjut dalam pada Pasal 42 dan 43 UUPPLH. Kedua pasal ini diterangkan lebih lanjut di dalam PP Instrumen Ekonomi.

Menurut UUPPLH, instrumen ekonomi meliputi:23

a). perencanaan pembangunan dan kegiatan ekonomi, ${ }^{24}$ yang terdiri atas: i). neraca sumber daya alam dan lingkungan hidup; ii). penyusunan produk domestik bruto dan produk domestik regional bruto yang mencakup penyusutan sumber daya alam dan kerusakan lingkungan hidup; iii). mekanisme kompensasi/imbal jasa lingkungan hidup antardaerah; dan iv). internalisasi biaya lingkungan hidup. ${ }^{25}$

b). pendanaan lingkungan hidup, 26 yang terdiri atas: i). dana jaminan pemulihan lingkungan hidup; ii). dana penanggulangan pencemaran dan/atau kerusakan dan pemulihan lingkungan hidup; dan iii). dana amanah/bantuan untuk konservasi. ${ }^{27}$

c). insentif dan/atau disinsentif, ${ }^{28}$ yang terdiri atas: i). pengadaan barang dan jasa yang ramah lingkungan hidup; ii). penerapan pajak, retribusi, dan subsidi lingkungan hidup; iii). pengembangan sistem lembaga keuangan dan pasar modal yang ramah lingkungan hidup; iv). pengembangan sistem perdagangan izin pembuangan limbah dan/atau emisi; v). pengembangan sistem pembayaran jasa lingkungan hidup; vi). pengembangan asuransi lingkungan hidup; vii). pengembangan sistem label ramah lingkungan hidup; dan viii). sistem penghargaan kinerja di bidang perlindungan dan pengelolaan lingkungan hidup. ${ }^{29}$

Dari uraian di atas, terlihat bahwa UUPPLH mengenal dua instrumen/pendekatan penaatan, yaitu penegakan hukum dan instrumen ekonomi. Ke dalam instrumen ekonomi dimasukkan pula berbagai upaya yang akan memberikan dorongan atau ancaman non-

${ }^{23}$ UUPPLH, Pasal 42 ayat (2).

${ }^{24}$ Ini adalah instrumen berupa "upaya internalisasi aspek lingkungan hidup ke dalam perencanaan dan penyelenggaraan pembangunan dan kegiatan ekonomi". UUPPLH, Penjelasan Pasal 42 ayat (2) huruf a.

${ }_{25}$ UUPPLH, Pasal 43 ayat (1) dan Penjelasannya. Lihat pula: PP Instrumen Ekonomi, Pasal 4-19.

${ }^{26}$ Ini adalah "sistem dan mekanisme penghimpunan dan pengelolaan dana yang digunakan bagi pembiayaan upaya perlindungan dan pengelolaan lingkungan hidup". UUPPLH, Penjelasan Pasal 42 ayat (2) huruf b.

27 UUPPLH, Pasal 43 ayat (2) dan Penjelasannya. Lihat Pula: PP Instrumen Ekonomi, Pasal 20-30.

28 Insentif adalah "upaya memberikan dorongan atau daya tarik secara moneter dan/atau non-moneter kepada setiap orang ataupun Pemerintah dan pemerintah daerah agar melakukan kegiatan yang berdampak positif pada cadangan sumber daya alam dan kualitas fungsi lingkungan hidup". Sedangkan disinsentif adalah "pengenaan beban atau ancaman secara moneter dan/atau non-moneter kepada setiap orang ataupun Pemerintah dan pemerintah daerah agar mengurangi kegiatan yang berdampak negatif pada cadangan sumber daya alam dan kualitas fungsi lingkungan hidup." UUPPLH, Penjelasan Pasal 42 ayat (2) huruf c.

${ }^{29}$ UUPPLH, Pasal 43 ayat (3) dan Penjelasannya. Lihat pula: PP Instrumen Ekonomi, Pasal 31-50. 
Instrumen Ekonomi, Command and Control, dan Instrumen Lainnya: Kawan atau Lawan?

moneter, seperti label dan sistem penghargaan lingkungan. Selain itu, ke dalam instrumen ekonomi juga dimasukkan instrumen GDP hijau dan neraca sumber daya alam.

\section{Instrumen Penaatan Lingkungan: dari CAC Menuju Smart Regulation}

$\mathrm{O}_{\mathrm{i}}$ rts menjelaskan perkembangan hukum lingkungan ke dalam tiga tahap, yaitu CAC, instrumen ekonomi, dan instrumen refleksif. ${ }^{30}$ Pembagian yang sama juga dapat dilihat dalam tulisan Stewart. ${ }^{31}$

Menurut Orts, sebagai pendekatan pertama untuk penaatan lingkungan, CAC berupaya mencapai perlindungan lingkungan melalui peraturan dari pemerintah yang menentukan bagaimana individu (pihak yang diatur) harus bertindak. ${ }^{32}$ Dalam perkembangannya, pendekatan CAC memperoleh banyak kritik dan dianggap kurang memadai dalam mendorong penaatan lingkungan. Karena itulah para ahli kemudian memperkenalkan generasi kedua dari pendekatan penaatan lingkungan, yaitu pendekatan pasar (market-based approach), atau instrumen ekonomi. ${ }^{33}$ Menurut Orts, instrumen ekonomi bertujuan untuk mempengaruhi pasar secara artifisial agar setiap pelaku di dalam pasar terdorong untuk mempertimbangkan biaya pencemaran yang selama ini dianggap sebagai biaya eksternal. ${ }^{34}$ Dalam instrumen ekonomi, hukum lingkungan berfungsi untuk memaksa para pembuat keputusan menginternalkan biaya-biaya sosial sehingga tidak ada lagi perbedaan antara biaya marjinal sosial dengan biaya marjinal privat. ${ }^{35}$ Dengan cara ini semua pihak akan dipaksa atau didorong untuk memasukkan pertimbangan biaya lingkungan (environmental costs) ke dalam pengambilan keputusannya.

Dalam perkembangan selanjutnya, inovasi pengelolaan lingkungan melahirkan pendekatan lebih baru lagi, yaitu pendekatan hukum refleksif. Berbeda dari pendekatan CAC

\footnotetext{
${ }^{30}$ Eric W. Orts, “A Reflexive Model of Environmental Regulation”, Business Ethics Quarterly, Vol. 5(4), Oct. (1995a), hlm. 781-787.

${ }^{31}$ Richard B. Stewart, "A New Generation of Environmental Regulation?”, Capital University Law Review, Vol. 29 (2001).

32 Eric W. Orts (1995a), Op Cit., hlm. 781.

${ }^{33}$ Ibid., hlm. 783.

${ }^{34}$ Eric W. Orts, “Reflexive Environmental Law”, Northwestern University Law Review, Vol. 89 (1995b), hlm. 1242.

${ }^{35}$ Dalam pasar yang kompetitif, harga (P) akan ditetapkan sesuai dengan biaya privat marjinal (Marginal Private Cost-MC). Eksternalitas terjadi ketika MC ternyata tidak merefleksikan biaya yang sesungguhnya, karena sebagian biaya, dalam hal ini biaya lingkungan (marginal environmental cost-MEC), ternyata dikeluarkan/tidak dipertimbangkan dalam komponen biaya. Dalam situasi ini, biaya sosial marjinal (Marginal Social Costs - MSC) adalah jumlah dari MC dan MEC. Apabila biaya lingkungan di atas dipertimbangkan, maka harga seharusnya diset sama dengan MSC. Karenanya, dengan internalisasi biaya-biaya lingkungan tersebut, harga barang akan ditetapkan sebesar: $\mathrm{P}=\mathrm{MSC}=\mathrm{MC}+\mathrm{MEC}$.

Lihat: David Hunter, James Salzman, Durwood Zaelke, 1998, International Environmental Law and Policy, New York: Foundation Press, hlm. 108.
} 
dan instrumen ekonomi yang masih memerlukan peran sentral pemerintah, fungsi pemerintah di dalam kebijakan hukum lingkungan refleksif sangatlah terbatas. Dalam hukum refleksif, pemerintah hanya berfungsi sebagai pendorong atau fasilitator berbagai program sukarela terkait pengelolaan lingkungan. Dalam sistem ini, industri atau aktor non-negara yang selama ini menjadi target dari peraturan, justru bertindak aktif dalam merencanakan, mempromosikan, dan mengelola program sukarela tersebut. Dalam pandangan Orts, hukum lingkungan yang refleksif adalah:

"a legal theory and a practical approach to regulation that seeks to encourage self-reflective and self-critical processes within social institutions concerning the effects they have on the natural environment. In other words, reflexive environmental law aims to establish internal evaluative procedures and patterns of decision making within institutions to lessen environmental harm and to increase environmental benefit." 36

Menurut Orts, hukum lingkungan refleksif memiliki ciri, antara lain: Pertama, hukum lingkungan refleksif bersifat kritis terhadap diri sendiri (self-critical). Hukum refleksif memahami keterbatasan hukum sebagai alat pendorong perubahan ketika dihadapkan pada persoalan sosial yang kompleks. Karena itu, hukum refleksif berangkat dari kemampuan mereka yang biasanya menjadi pihak yang diatur (regulated communities) untuk melakukan kritik diri (self-critical) dan penilaian/referensi diri (self-referential), sebagai dasar untuk mengatur diri sendiri. Kedua, hukum lingkungan refleksif mendorong peningkatan kapasitas dan peran dari institusi dan sistem di luar sistem hukum. Dalam hal ini, salah satu upaya yang didorong melalui hukum refleksif adalah keterbukaan informasi kepada publik terkait kinerja pengelolaan lingkungan usaha/kegiatan. ${ }^{37}$ Ketiga, hukum lingkungan berupaya untuk mendorong pihak ketiga (intermediate), selain dari pasar dan negara, dalam upaya perlindungan lingkungan. 38

Menurut Orts, hukum lingkungan refleksif diwujudkan dalam berbagai instrumen, di antaranya, instrumen sukarela (voluntarism), keterbukaan informasi kepada publik (public disclosure), sertifikasi oleh pihak ketiga (third-party certification), dan partisipasi pengelolaan lingkungan oleh kelompok kepentingan (participation by public interest groups). Selain itu,

\footnotetext{
${ }^{36}$ Eric W. Orts (1995a), Op Cit., hlm. 780.

${ }^{37}$ Eric W. Orts (1995b), Op Cit., hlm. 1232.

38 Ibid., hlm. 1253-1254.
} 
Instrumen Ekonomi, Command and Control, dan Instrumen Lainnya: Kawan atau Lawan?

terdapat pula prosedur bagi pelembagaan refleksi diri dan kritik diri (institutional self-reflection and self-criticism) ${ }^{39}$

Apabila ketiga tahap yang dijelaskan Orts dan Stewart di atas memfokuskan pada pencarian jenis instrumen penaatan yang paling tepat, maka tahap keempat yang dijelaskan oleh Arnold justru merupakan upaya untuk mencari bentuk kombinasi instrumen dan aktor yang tepat. Dalam hal ini, Arnold mengatakan bahwa hukum lingkungan generasi keempat ditandai dengan pendekatan integratif dan multimoda. Artinya, pendekatan ini mendorong digunakannya beberapa metode perlindungan lingkungan. ${ }^{40}$ Lebih jauh lagi, Arnold mengatakan bahwa:

"The use of multiple modes or methods in environmental protection can occur in at least three different ways. Multimodality may involve the use of multiple categories of policy instruments, such as command-and-control regulation, tort liability, public education, and market incentives. Multimodality can also describe the use of more than one specific tool or mechanism for environmental protection, such as water usage restrictions, water conservation pricing methods, concurrency requirements in land development approvals (i.e., requiring demonstration of adequate water supplies and infrastructure), and monetary damages for excessive groundwater pumping. Finally, multimodality might refer to the use of multiple institutions, organizations, groups, or authoritative entities to engage in environmental protection...." 41

Pendekatan yang dikemukakan oleh Arnold di atas memperlihatkan bahwa instrumeninstrumen penaatan lingkungan tidak lagi dipandang sebagai alternatif dan bertentangan antara satu dengan yang lainnya. Sebaliknya, yang dicari adalah kemungkinan penerapan secara komplementer dari berbagai instrumen, sehingga dapat menghasilkan kombinasi (policy mixes) yang lebih baik dibandingkan dengan penerapan instrumen penaatan secara sendirisendiri. Selain itu, pendekatan ini juga memperlihatkan adanya kebutuhan untuk membuka kemungkinan bagi keterlibatan pemerintah dan pelaku usaha, serta masyarakat, baik yang

\footnotetext{
${ }^{39}$ Eric W. Orts (1995a), Op Cit., hlm. 788.

Sementara itu, dalam pandangan Stewart, hukum refleksif bertujuan untuk mendorong internalisasi kaidah perlindungan lingkungan oleh pelaku usaha, dengan sedikit (atau bahkan tanpa adanya) arahan secara langsung dari pihak eksternal (pemerintah). Menurut Stewart, instrumen hukum refleksif biasanya diwujudkan dalam bentuk peraturan mengenai informasi (information regulation), sistem audit dan pengelolaan lingkungan (environmental audit and management systems), dan sistem penaatan alternatif (alternative compliance programs). Richard B. Stewart, Op Cit., hlm. 127-133.

${ }^{40}$ Craig Anthony Arnold, 2011, "Fourth-Generation Environmental Law: Integrationist and Multimodal”, William \& Mary Environmental Law and Policy Review, Vol. 35:3, Spring, hlm. 793.

${ }^{41}$ Ibid., hlm. 775
} 
komersial maupun non-komersial, di dalam penyusunan dan penerapan regulasi lingkungan hidup.

Dengan demikian, terlihat bahwa tidak ada satu instrumen yang superior dibandingkan instrumen lainnya. Hal ini bahkan diakui pula oleh Orts, seorang penulis yang mengusung instrumen penaatan refleksif. Menurutnya, "I do not regard reflexive environmental law as necessarily superior to conventional methods of command-and-control or market-based regulation. The type of regulation best suited for a particular problem depends on a pragmatic assessment of the circumstances." 42

Berangkat dari kelebihan dan keterbatasan tiap instrumen, maka yang diperlukan adalah bagaimana melengkapi satu instrumen dengan instrumen lainnya, agar instrumen-instrumen tersebut berkerja dengan saling memperkuat satu sama lain. Barangkali, di sini perlu diungkapkan pandangan Gunningham dan Sinclair, yang secara tegas menyatakan bahwa "the best means of overcoming the deficiencies of individual instruments, while taking advantage of their strengths, is through the design of combinations of instruments." 43

Instrumen CAC (Command and Control), Instrumen Ekonomi, Atur Diri Sendiri (SelfRegulation), Instrumen Sukarela, dan Regulasi Informasi

$\mathrm{B}^{\mathrm{a}}$ agian ini akan menjelaskan bahwa, berbeda dari pengaturan menurut UUPPLH dan PP Instrumen Ekonomi, instrumen penaatan lingkungan tidak hanya terdiri atas dua jenis pendekatan, yaitu CAC dan instrumen ekonomi. Selain itu, bagian ini akan menunjukkan bahwa label dan sistem penghargaan lingkungan tidak termasuk ke dalam instrumen ekonomi.

Tulisan ini akan mengikuti pembagian instrumen yang diberikan oleh Gunningham et al. di dalam buku mereka Smart Regulation: Designing Environmental Policy. Menurut Gunningham et al. instrumen penaatan dibagi ke dalam beberapa kelompok berikut: instrumen CAC, instrumen ekonomi, instrumen atur diri sendiri (self regulation), instrumen sukarela

\footnotetext{
${ }^{42}$ Eric W. Orts (1995b), Op Cit., hlm. 1234.

Pengakuan yang sama juga diutarakan oleh Stewart pada saat ia membahas instrumen refleksif. Menurutnya, meskipun secara teoretis instrumen refleksif dapat saja menghilangkan sama sekali peran regulasi langsung (direct regulation), yang tidak lain adalah bentuk pendekatan CAC, akan tetapi di dalam prakteknya instrumen refleksif ini bekerja justru untuk memperkuat dan melengkapi regulasi langsung. Lihat: Richard Stewart, op cit., hlm. 148149.

Pandangan serupa juga dikemukakan oleh: J.G. Nel dan J.A. Wessels, "How to Use Voluntary, Self-Regulatory and Alternative Environmental Compliance Tools: Some Lessons Learnt", Potchefstroom Electronic Law Journal, Vol. 13 (2010), hlm. 53-54. Lihat pula: Lawrence H. Goulder dan Ian W. H. Parry, “Instrument Choice in Environmental Policy", Review of Environmental Economics and Policy, Vol. 2:2 (summer 2008), hlm. 153.

${ }^{43}$ Neil Gunningham dan Darren Sinclair, 1999, "Integrative Regulation: A Principle-Based Approach to Environmental Policy", Law and Social Inquiry, Vol. 24, hlm. 859.
} 
Instrumen Ekonomi, Command and Control, dan Instrumen Lainnya: Kawan atau Lawan?

(voluntarism), instrumen pasar "hijau" (market environmentalism), serta instrumen pendidikan dan informasi (education and information instruments). ${ }^{44}$

1. Instrumen CAC atau Regulasi Langsung (Direct Regulation)

Sebagaimana telah diuraikan pada bagian sebelumnya, instrumen penaatan yang paling banyak digunakan adalah instrumen berdasarkan pendekatan atur dan awasi (Command and Control, CAC). Pendekatan CAC dianggap memiliki beberapa keunggulan. Pendekatan ini memiliki tingkat kehandalan ${ }^{45}$ yang tinggi karena dianggap dapat memberikan kejelasan mengenai perilaku yang diharapkan, sehingga memudahkan identifikasi terhadap pelanggaran. Selain itu, pendekatan CAC pun relatif berhasil digunakan di beberapa negara untuk mengatasi persoalan pencemaran dari sumber tertentu (point-source pollution). ${ }^{46}$ Selanjutnya, pendekatan CAC dapat dianggap merupakan pendekatan yang paling dikenal dan diterapkan, sehingga pemerintah memiliki pengalaman dan pengetahun yang cukup baik terhadap pendekatan CAC ini. Terakhir, apabila CAC berfungsi baik, pelanggaran akan dapat dideteksi dan

${ }^{44}$ Neil Gunningham, Peter Grabosky, dan Darren Sinclair, (2004), Op Cit., hlm. 37-88.

Perlu diutarakan di sini bahwa untuk menjelaskan masing-masing instrumen, tulisan ini akan menggunakan berbagai literatur terkait, di luar dari buku Guningham, et al. Selanjutnya, apabila dirasa perlu, tulisan ini akan memberikan komentar terhadap pembagian yang diberikan oleh Guningham, serta menggunakan klasifikasi yang sedikit menyimpang dari pembagian jenis instrumen menurut mereka.

Sebagai perbandingan, dapat pula diperhatikan pandangan dari Wurel, Zito, dan Jordan. Pengarang ini menggunakan istilah regulation untuk menjelaskan instrumen CAC, sedangkan instrumen non-CAC disebutnya dengan New Environmental Policy Instruments (NEPIs), instrumen lingkungan hidup baru. NEPIs terdiri atas instrumen informasi (informational instruments), eco-labels, skema pengelolaan lingkungan sukarela (environmental management schemes), perjanjian sukarela (voluntary agreements), dan instrumen ekonomi (market based instruments). Lihat: Rüdiger Wurzel, Anthony Zito, dan Andrew Jordan, "Smart (and Not-So-Smart) Mixes of New Environmental Policy Instruments", dalam: Judith van Erp, et al., Smart Mixes for Transboundary Environmental Harm (Cambridge: Cambridge University Press, 2019), hlm. 72-86.

Ketiga pengarang tersebut membahas pola penerapan NEPI di berbagai negara Eropa. Mereka menyimpulkan bahwa NEPI di Eropa diterapkan bukan untuk menggantikan (supplant), melainkan untuk melengkapi (supplement) instrumen "lama" berdasarkan pendekatan CAC. Karena itu, pengarang tersebut masih menemukan adanya campuran (hybridization) antara instrumen lama berdasarkan pendekatan CAC dengan instrumen baru (NEPIs) berdasarkan pendekatan non-CAC. Lihat: Ibid., hlm. 90-91.

Bandingkan pula dengan pandangan Taylor et al. yang membagi instrumen ke dalam: (i) CAC/peraturan secara langsung (direct 'command and control' regulation), (ii) instrumen ekonomi (economic instruments), (iii) instrumen informasi (information-based instruments), (iv) co-regulation and self-regulation, dan (v) instrumen dukungan mekanisme dan pembangunan kapasitas (support mechanisms and capacity building). C. Taylor, S. Pollard, S. Rocks, dan A. Angus. "Selecting Policy Instruments for Better Environmental Regulation: a Critique and Future Research Agenda", Environmental Policy and Governance, Vol. 22:4 (2012), hlm. 273-282.

Sementara itu, Faure dan Partain membagi instrumen penaatan lingkungan ke dalam: pertanggungjawaban perdata (civil liability rule); CAC; instrumen ekonomi (market-based instruments); suasive mechanism, di mana pemerintah menyetir perlilaku warganya melalui penggunaan pendekatan "nudging"; mekanisme sukarela dan privat (voluntary and privat mechanisms), dan campuran berbagai instrumen (smart mixes). Michael G. Faure dan Roy A. Partain, Environmental Law and Economics: Theory and Practice (Cambridge: Cambridge University Press, 2019), 29-34.

${ }^{45}$ Dalam bahasa Gunningham et al., hal ini disebut dependability.

${ }^{46}$ Neil Gunningham, Peter Grabosky, dan Darren Sinclair (2004), Op Cit., hlm. 41-42. 
ditindaklanjuti dengan cepat, tanpa perlu menunggu terjadi pencemaran. Karenanya, pendekatan CAC memiliki pula fungsi pencegahan yang sangat baik.

Menurut Santosa, efektivitas pendekatan CAC mengandalkan terpenuhinya tiga faktor, yaitu: Pertama, kemampuan penegak hukum untuk mendeteksi adanya pelanggaran; kedua, adanya tanggapan/respons dari penegak hukum yang cepat dan pasti (swift and sure responses) atas terjadinya pelanggaran; dan, ketiga, adanya sanksi yang memadai. Menurut Santosa pula, CAC di Indonesia menghadapi masalah serius, karena tidak adanya sistem pengawasan dan penataan, respons yang tebang pilih dalam arti seringkali inkonsisten dan diskriminatif, serta jarangnya penjatuhan sanksi kepada para pelanggar. ${ }^{47}$

\section{Instrumen ekonomi}

Penggunaan instrumen ekonomi, atau disebut juga pendekatan berbasis mekanisme pasar (market-based approach), erat kaitannya dengan apa yang disebut sebagai prinsip pencemar membayar (Polluter Pays Principle). ${ }^{48}$ Instrumen ekonomi biasanya terdiri atas instrumen pajak lingkungan (environmental tax/charge), izin yang dapat diperjualbelikan (tradeable permit), sistem deposito yang dapat dikembalikan (deposit refundable system atau performance bonds), hak kepemilikan (property right), pertanggungjawaban perdata (civil liability), instrumen finansial (financial instruments), dan subsidi terkait dengan pengelolaan lingkungan (subsidy). ${ }^{49}$

\footnotetext{
47 Mas Achmad Santosa, 2001, Good Governance dan Hukum Lingkungan, Jakarta: ICEL, hlm. 236.

${ }^{48}$ Menurut Boyle, 1994, prinsip pencemar membayar ialah merupakan sebuah kebijakan ekonomi yang mengalokasikan biaya-biaya pencemaran atau kerusakan lingkungan. Lihat: Alan Boyle, “Economic Growth and Protection of the Environment: The Impact of International Law and Policy", dalam: Alan Boyle (ed.), Environmental Regulation and Economic Growth, Oxford: Oxford University Press, hlm. 179.

Dengan demikian prinsip ini merupakan wujud dari internalisasi eksternalitas, di mana pencemar harus membayar biaya-biaya lingkungan yang dihasilkannya, dalam rangka mencegah dan mengatasi pencemaran sebagai akibat dari kegiatannya. Semakin banyak pencemaran yang dihasilkan maka akan semakin besar biaya yang dikeluarkan. Akibatnya, produk yang ramah lingkungan akan menjadi lebih murah dari pada yang tidak ramah lingkungan, dan pada akhirnya mendorong orang untuk tidak melakukan kegiatan yang memiliki dampak negatif bagi lingkungan.

${ }^{49}$ Pembagian ini didasarkan pada pandangan Gunningham dan Sinclair. Lihat: Neil Gunningham dan Darren Sinclair (1999a), Op Cit., hlm. 53-54.

Karena keterbatasan ruang, tulisan ini sayangnya hanya dapat memberikan gambaran umum mengenai pengelompokkan instrumen ekonomi. Untuk penjelasan mendetail dari tiap bentuk instrumen ekonomi, pembaca dapat melihatnya di dalam berberap literatur berikut.

Untuk diskusi lebih lanjut mengenai pajak lingkungan, lihat misalnya: Michael Faure, Marjan Peeters and Andri G. Wibisana, "Economic Instruments: Suited to Developing Countries?”, dalam Michael Faure dan Nicole Niessen (eds.), Environmental Law in Development: Lessons from the Indonesian Experience (Cheltenham, UK: Edward Elgar, 2006), hlm. 225-231; R. Kerry Turner, David Pearce, dan Ian Bateman, Op Cit., hlm. 166-180; David Wilkinson, Environment and Law (New York: Routledge, 2002), hlm. 182-186; dan Anthony Ogus, "Nudging and Rectifying: The Use of Fiscal Instruments for Regulatory Purposes", Legal Studies, Vol. 19 (1999).

Untuk diskusi lebih jauh mengenai izin yang dapat diperjualbelikan, lihat misalnya: Robert V. Percival, et al., Environmental Regulation: Law, Science, and Policy, 7th ed. (New York: Wolters Kluwer Law \& Business, 2013), hlm.
} 
Instrumen Ekonomi, Command and Control, dan Instrumen Lainnya: Kawan atau Lawan?

Selanjutnya, Gunningham et al. mengelompokkan pula instrumen ekonomi tersebut ke dalam tiga sub-kelompok. Pertama, adalah instrumen ekonomi yang diberlakukan secara umum (broad-based economic instruments), dalam arti bahwa instrumen ini diberlakukan kepada industri secara keseluruhan tanpa membedakan pilihan teknologi atau sektor di dalam industri, atau tanpa menetapkan standar kinerja tertentu bagi usaha/kegiatan. Gunningham et al. memasukkan pajak/pungutan lingkungan dan izin yang dapat diperjualbelikan ke dalam kelompok ini. Kedua, adalah instrumen ekonomi yang memberikan insentif pada sisi suplai (supply-side incentives), yaitu instrumen ekonomi yang memberikan insentif finansial kepada pelaku usaha/kegiatan dalam rangka membantu mereka mematuhi standar kinerja atau standar teknologi tertentu. Oleh

624-625; Michael Faure, Marjan Peeters and Andri G. Wibisana, Op Cit., hlm. 231-241; R. Kerry Turner, David Pearce, dan Ian Bateman, Op. Cit., hlm. 181-189; David Wilkinson, Op Cit., hlm. 188-189.

Untuk diskusi lebih jauh mengenai sistem deposito yang dapat dikembalikan, lihat misalnya: Margaret Walls, "Deposit-Refund Systems in Practice and Theory", RFF Discussion Paper, November 2011 RFF DP 11-47, terserdia pada: <https://media.rff.org/documents/RFF-DP-11-47.pdf>; J. Boyd, “A Market-Based Analysis of Financial Insurance Issues Associated with US Natural Resource Damage Liability”, dalam: M. Faure (ed.), Deterrence, Insurability, and Compensation in Environmental Liability: Future Developments in the European Union (Vienna: Springer, 2003), hlm. 262-263; Linlin Cheng dan Jeffrey G. Skousen, "Comparison of International Mine Reclamation Bonding Systems with Recommendations for China", International Journal of Coal Science E Technology, Vol. 4:2 (2017); Robert Costanza dan Charles Perrings, "A Flexible Assurance Bonding System for Improved Environmental Management", Ecological Economics, Vol. 2 (1990); dan Robert Costanza dan Laura Cornwell, "The 4P Approach to Dealing with Scientific Uncertainty", Environment, Vol. $34: 9$ (1992); dan Olli-Pekka Kuusela \& Gregory S. Amache, "A Review of Performance Bonding in Forest Policy Settings", Current Forestry Repports, Vol. 2:3 (2016), hlm. 17-27.

Penjelasan awal terkait manfaat hak kepemilikan (property right) bagi pengelolaan lingkungan dapat dilihat dalam The Tragedy of the Commons-nya Hardin. Di dalam tulisan tersebut, Hardin memberikan contoh kerusakan lingkungan dari pemakaian sebuah barang publik berupa padang rumput oleh para peternak. Dengan asumsi bahwa setiap orang memiliki sifat self-interest dan profit maximizing, Hardin berpendapat bahwa orang yang rasional justru akan memanfaatkan padang rumput tersebut untuk keuntungan pribadi yang sebesar-besarnya. Apabila setiap peternak berpikir rasional seperti ini, maka mereka hanya memikirkan bagaimana memanfaatkan sumber daya alam atau jasa lingkungan tanpa peduli bahwa pemanfaatan yang berlebihan itu akan mengarah pada kehancuran. Setiap peternak hanya mau menjadi free-rider, penumpang gelap, dari usaha perbaikan yang dilakukan oleh orang lain. Akibatnya, padang rumput tersebut akan mengalami overexploitation, kehancuran. Inilah yang dia sebut sebagai tragedi. Selanjutnya Hardin berpendapat pula bahwa pencemaran lingkungan merupakan contoh lain dari the tragedy of the commons. Lihat: Garret Hardin, "The Tragedy of the Commons", Science, Vol. 162, 1968, hlm. 1244-1245. Atas persoalan ini, Hardin menawarkan solusi berupa pemberian hak kepemilikan atau hak ekslusif atas the commons kepada pihak tertentu. Menurutnya, "We might sell them off as private property. We might keep them as public property, but allocate the right to enter them. The allocation might be on the basis of wealth, by the use of an auction system. It might be on the basis of merit, as defined by some agreed-upon standards. It might be by lottery. Or it might be on a first-come, first served basis, administered to long queues." Ibid., hlm. 1245. Terkait penjelasan lanjutan mengenai property right, lihat: Neil Gunningham, Peter Grabosky, dan Darren Sinclair (2004), Op Cit., hlm. 70-71.

Untuk diskusi mengenai pertanggungjawaban perdata (liability), lihat misalnya: Ibid., hlm. 78-87. Terkait instrumen finansial (financial instruments), Gunningham et al. menjelaskan bahwa instrumen finansial dilakukan dengan memobilisasi dana yang ditujukan untuk konservasi dan perlindungan lingkungan. Menurut mereka, termasuk ke dalam instrumen finansial ini adalah berbagai bentuk pendanaan lingkungan (environmental funds), seperti revolving funds, trust funds, subsidised interest rates, dan soft loans. Lihat: Ibid., hlm. 77-78.

Untuk diskusi lebih jauh mengenai subsidi terkait dengan pengelolaan lingkungan, lihat misalnya: Charles D. Patterson III, "Environmental Taxes and Subsidies: What is the Appropriate Fiscal Policy for Dealing with Modern Environmental Problems?", William \& Mary Environmental Law and Policy Review, Vol. 24:1 (2000), hlm. 143-151; Wallace Oates dan William Baumol, op. cit., hlm. 96-98; David Wilkinson, Op Cit., hlm. 186-187. 
Gunningham et al., subsidi dianggap sebagai contoh dari kelompok instrumen ekonomi ini. Ketiga, instrumen ekonomi berupa pertanggungjawaban perdata. ${ }^{50}$

3. Self-Regulation

Gunningham et al. menjelaskan self-regulation sebagai "a process whereby an organized group regulates the behaviour of its members." 51 Dari uraian di atas terlihat bahwa selfregulation merupakan aturan yang ditetapkan oleh organisasi, termasuk industri, kepada anggotanya. Berdasarkan pengertian ini maka terlihat bahwa aturan dibuat oleh industri, dan bukan dibuat oleh pemerintah atau oleh individu. Gunningham dan Sinclair, dalam salah satu tulisan mereka, memasukkan self-regulation sebagai perwujudan dari "ecological modernisation" (modernisasi ekologi), di mana industri berinisiatif untuk membuat program pengelolaan lingkungan sendiri.52

Menurut Gunningham, pada dasarnya self-regulation dapat dibedakan ke dalam beberapa bentuk, yaitu: a). self-regulation secara total atau sukarela (total or voluntary selfregulation), di mana industri menetapkan aturan (code of practice), mekanisme penegakan hukum, atau mekanisme pembuatan aturan secara mandiri tanpa campur tangan pemerintah. b). self-regulation yang diperintahkan (mandated self-regulation). Jenis ini melibatkan campur tangan pemerintah secara langsung dalam bentuk aturan yang mensyaratkan agar industri mengontrol perilakunya sendiri, atau persetujuan atas aturan dan mekanisme kontrol dan penegakan hukum yang dibuat sendiri oleh industri. c). self-regulation semi wajib (mandatory partial self-regulation), di mana pemerintah menetapkan aturan umum yang mewajibkan agar industri membuat beberapa (sebagian) aturan dan menetapkan mekanisme penegakan hukum sendiri atas aturan tersebut. ${ }^{53}$

${ }^{50}$ Neil Gunningham, Peter Grabosky, dan Darren Sinclair (2004), Op Cit., hlm. 424-425.

51 Ibid., hlm. 50.

${ }^{52}$ Neil Gunningham dan Darren Sinclair, 2002, Leaders and Laggards: Next-Generation Environmental Regulation, Sheffield: Greenleaf Publishing Ltd., hlm. 198-199.

${ }^{53}$ Neil Gunningham, Peter Grabosky, dan Darren Sinclair (2004), Op Cit., hlm. 51.

Sebagai perbandingan, dapat pula kita melihat pembagian self-regulation menurut Hemphill, sebagaimana dikutip oleh Iannuzzi, Jr. Menurut pengarang ini, self-regulation dapat dibedakan ke dalam dua bentuk. Pada satu sisi instrumen ini dapat berupa penentuan standar tertentu secara sukarela oleh pelaku usaha/kegiatan atau industri pada saat tidak ada peraturan perundang-undangan yang mengatur standar tersebut. Pada sisi lain, instrumen ini dapat pula berupa penentuan standar oleh pelaku usaha/kegiatan atau industri dalam rangka menaati peraturan yang berlaku, atau untuk mencapai target yang lebih baik dari peraturan yang berlaku. Lihat: Alphonse Iannuzzi, Jr., Industry Self-Regulation and Voluntary Environmental Compliance (Washington, DC: Lewis Publishers, 2002), hlm. 23.

Menurut Beattie, penerapan self-regulation perlu dilakukan secara selektif untuk kasus-kasus di mana self-regulation akan memberikan hasil yang lebih baik dibandingkan dengan regulasi (CAC). Untuk itu, penerapan self-regulation perlu memperhatikan beberapa syarata, yaitu adanya pengaman (safeguards) terhadap ketidakadilan (unfairness), penutupan informasi (secrecy), dan kurangya akuntabilitas publik. Karen Beattie, "Fairness, Openness and SelfRegulation: An Examination of Administrative Law Values and the Use of Voluntary and Self-Regulatory 


\section{Instrumen Sukarela}

Secara umum, penaatan sukarela dibagi ke dalam empat kelompok utama. Pertama, komitmen sepihak oleh pelaku usaha/kegiatan, di mana pelaku usaha/kegiatan membuat program perbaikan lingkungan sendiri, dan kemudian menginformasikan hal ini kepada publik atau pemegang saham. Dalam hal ini, target perbaikan lingkungan ditentukan sendiri oleh pelaku usaha/kegiatan. Demikian pula halnya dengan monitoring, tata kelola, dan penaatan terhadap target tersebut. Kedua, perjanjian privat antara pencemar (polluters) dan korbannya (pollutees). Dalam bentuk ini, perusahaan atau kelompok usaha dan pihak yang diperkirakan akan terkena dampak dari usaha/kegiatan mereka mengadakan perjanjian yang berisi, antara lain, program pengelolaan lingkungan atau penerapan teknologi tertentu untuk mengurangi pencemaran. Ketiga, adalah perjanjian antara industri dengan pemerintah. Perjanjian semacam ini biasanya memuat target penurunan pencemaran (emisi) tertentu yang hendak dicapai dalam waktu tertentu. Salah satu ciri penting dari perjanjian ini adalah adanya keinginan untuk melakukan penurunan pencemaran ketika hal tersebut belum diatur di dalam peraturan perundang-undangan. Keempat, program sukarela yang dikembangkan oleh pemerintah, dan pelaku usaha/kegiatan diundang untuk terlibat di dalamnya. Misalnya saja pelaku usaha/kegiatan menyetujui untuk terlibat dalam program tertentu yang digagas oleh Pemerintah. Sebagai imbalannya, pelaku usaha/kegiatan ini memperoleh kemudahan-kemudahan tertentu, atau memperoleh reputasi yang baik. ${ }^{54}$

Instrumen penaatan sukarela dapat pula dibedakan berdasarkan target atau implementasi tertentu. Dalam hal ini, pada satu sisi penaatan sukarela dapat dilakukan melalui penentuan tujuan atau target tertentu, misalnya penurunan emisi, yang belum diatur oleh pemerintah. Penaatan sukarela seperti ini disebut sebagai target-based voluntary approach. Pada sisi lain, penaataan sukarela dapat disusun dalam rangka penyesuaian kegiatan usaha dengan peraturan perundang-undangan, misalnya melalui penentuan cara untuk menaati baku mutu yang ditetapkan pemerintah. Penaatan sukarela seperti ini disebut sebagai implementation-based voluntary approach. 55 Contoh dari

Measures for Environmental Protection", Canadian Journal of Administrative Law \& Practice, Vol. 14 (2000-2001), hlm. 58-59.

54 OECD, 2003, Voluntary Approaches for Environmental Policy: Effectiveness, Efficiency and Usage in Policy Mixes Paris: OECD, hlm. 18-19.

${ }^{55} \mathrm{Ibid} ., \mathrm{hlm}$. 19. Istilah lain dapat dipergunakan untuk menjelaskan kelompok instrumen sukarela ini adalah "environmental management scheme". Untuk diskusi lebih lanjut mengenai skema pengelolaan lingkungan, baik ISO 
program sukarela implementasi ini antara lain audit lingkungan sukarela, ${ }^{56}$ mekanisme pemberian informasi, ${ }^{57}$ dan perjanjian sukarela (covenant). ${ }^{58}$

Gunningham dan Sinclair mengganggap beberapa instrumen sukarela, seperti perjanjian sukarela, sebagai wujud dari "environmental partnership" (kemitraan lingkungan). Menurut pengarang ini, pemerintah, pelaku usaha, masyarakat, dan LSM bekerja sama membentuk "green alliances" untuk menemukan instrumen penaatan lingkungan yang akan mendorong tercapainya win-win solution, dan tidak lagi mengandalkan pada ketentuan yang bersifat memaksa. Melalui mekanisme ini pula pelaku usaha didorong untuk mencapai hasil beyond compliance. ${ }^{59}$

\section{Instrumen Pendidikan dan Informasi (Education and Information Instruments)}

Gunningham et al. menyatakan bahwa instrumen pendidikan dan informasi terdiri atas berbagai instrumen yang cukup luas dan sering kali tumpang tindih. Mereka membagi instrumen ini ke dalam pelatihan dan pendidikan (education and training), mekanisme pelaporan oleh pelaku usaha/kegiatan (corporate environmental reporting), hak masyarakat atas informasi (community right to know), sertifikasi produk (product certification), dan sistem penghargaan. ${ }^{60}$

Secara umum, sistem pemberian pendidikan dan informasi dapat memiliki peran esensial dalam mendorong terjadinya perubahan ke arah perilaku ramah lingkungan.

maupun bentuk audit sukarela lainnya, lihat misalnya: David W. Case, 2006, "Changing Corporate Behavior through Environmental Management Systems", William and Mary Environmental Law and Policy Review, Vol. 31, Fall,

${ }^{56}$ David Wilkinson, Op Cit., hlm. 150-151; Aseem Prakash and Matthew Potoski, 2006, The Voluntary Environmentalists: Green Clubs, ISO 14001, and Voluntary Regulations (Cambridge: Cambridge University Press, 2006), hlm. 89-92; dan Rory Sullivan, Rethinking Voluntary Approaches in Environmental Policy (Cheltenham, UK: Edward Elgar, hlm. 70-72.

${ }^{57}$ Arthur P.J. Mol, 2008, Environmental Reform in the Information Age: The Contours of Informational Governance, Cambridge: Cambridge University Press, hlm. 254.

${ }^{58}$ David Wilkinson, op cit., hlm. 146-147; Edoardo Croci, 2005, "The Economics of Environmental Voluntary Agreements", dalam: Edoardo Croci (ed.), The Handbook of Environmental Voluntary Agreements: Design, Implementation and Evaluation Issues, Dordrecht: Springer, hlm. 11-20; Alphonse Iannuzzi, Jr., Op Cit., hlm. 19.

Perlu disampaikan di sini bahwa instrumen penaatan sukarela tidak selamanya akan memberikan hasil yang optimal. Kerret dan Tal, misalnya, menyimpulkan bahwa pada satu sisi instrumen sukarela mungkin dapat berfungsi untuk pemberdayaan lembaga pengelola lingkungan, terutama pada saat lembaga tersebut sedang mengembangkan infrastruktur pengaturan atau kapabilitas internal terkait informasi mengenai karakteristik usaha/kegiatan, keahlian personil, dan pengumpulan data hasil pemantauan. Namun pada sisi lain, terdapat bukti bahwa instrumen sukarela tidak selamanya akan menghasilkan penurunan emisi, perbaikan pengolaan lingkungan, dan pa kesadaran yang lebih baik dibandingkan dengan pendekatan CAC. Lihat: Dorit Kerret dan Alon Tal, "Greenwash or Green Gain? Predicting the Success and Evaluating The Effectiveness of Environmental Voluntary Agreements", Penn State Environmental Law Review, Vol. 14 (Fall, 2005), hlm. 37.

${ }_{59}$ Neil Gunningham dan Darren Sinclair (2002), hlm. 194-195.

${ }^{60}$ Neil Gunningham, Peter Grabosky, dan Darren Sinclair (2004), Op Cit., hlm. 60. Pemaparan sedikit berbeda diberikan oleh Gunningham dan Sinclair di dalam tulisan mereka yang lain, di mana kedua pengarang ini tidak memasukkan sistem penghargaan ke dalam bagian instrumen pendidikan dan informasi. Lihat: Neil Gunningham and Darren Sinclair (1999a), Op Cit., hlm. 54.. 
Instrumen Ekonomi, Command and Control, dan Instrumen Lainnya: Kawan atau Lawan?

Menurut Gunningham et al., sistem ini bekerja dengan baik terutama jika pada satu sisi mampu memanfaatkan sentimen self-interest pelaku usaha/kegiatan, sehingga perilaku ramah lingkungan memberikan daya tarik yang lebih besar dibandingkan dengan perilaku tidak ramah lingkungan; dan pada sisi lain mampu memberikan kesadaran pada pelaku usaha/kegiatan tentang pentingnya pengelolaan lingkungan yang baik. ${ }^{61}$

\section{Kombinasi Instrumen Penaatan dan Peran Para Aktor}

G unningham dan Holley mencatat bahwa strategi yang kurang intervensionis, seperti selfregulation atau instrumen sukarela, tampaknya akan kecil kemungkinannya untuk berhasil jika berjalan sendirian tanpa adanya dukungan dari pendekatan regulasi secara langsung (CAC). Misalnya, di bawah pendekatan sukarela, beberapa perusahaan mungkin akan tergoda untuk mengembangkan sistem pengelolaan lingkungan yang sulit dideteksi oleh auditor pihak ketiga. Hal ini dapat diatasi dengan dimunculkannya pendekatan CAC, berupa ancaman sanksi jika perusahaan gagal memenuhi target kinerja yang ditetapkan oleh negara. Demikian pula dengan instrumen ekonomi, seperti emisi yang dapat diperdagangkan, yang keberhasilannya pada gilirannya akan sangat tergantung pada efektivitas penegakan hukum secara langsung melalui pendekatan CAC. Karenanya, menurut Gunningham dan Holley, kondisi yang terbaik terjadi bukan lah ketika tata kelola (governance) bekerja dengan meninggalkan hukum dan pemerintah, tetapi tata kelola bekerja secara bersama (hybrid) dengan pemerintah. ${ }^{62}$ Upaya pencarian kombinasi instrumen yang ideal merupakan tujuan utama dari smart regulation.

Menurut Gunningham dan Sinclair, smart regulation merupakan penyempurnaan dari teori responsive regulation, ${ }^{63}$ yang sebelumnya dikembangkan oleh Ayres dan Braithwaite.

\footnotetext{
61Ibid., hlm. 68.

Perlu disampaikan di sini bahwa Gunningham et al. melihat pula beberapa kelemahan dan hal yang perlu memperoleh perhatian serius dari instrumen sistem pendidikan dan informasi.Di samping tergantung pada tidak adanya kesenjangan antara kepentingan publik dan kepentingan privat, keberhasilan instrumen pendidikan dan informasi juga sangat tergantung pada kemampuan publik untuk memberikan konsekuensi positif pada perilaku ramah lingkungan dan konsekuensi negatif pada perilaku sebaliknya. Untuk itu, syarat keberhasilan instrumen ini juga sangat tergantung pada kapasitas publik dalam mengetahui dan membedakan perilaku ramah lingkungan dari perilaku yang tidak ramah lingkungan. Ibid., hlm. 69.

${ }^{62}$ Neil Gunningham dan Cameron Holley, “Next-Generation Environmental Regulation: Law, Regulation, and Governance", Annual Review of Law and Social Science, Vol. 12 (2016), hlm. 286-287.

63Menurut Ayres dan Braithwaite, 1992, berdasarkan responsive regulation, pada awalnya penegak hukum biasanya akan berusaha menciptakan penaatan melalui cara persuasif. Apabila pendekatan ini gagal, maka respons penegak hukum meningkat menjadi peringatan tertulis. Apabila cara ini pun gagal, penegak hukum akan menerapkan denda administrasi (disebut sebagai civil monetary penalties). Apabila denda ini gagal, maka penegakan hukum akan ditempuh melalui tututan pidana. Apabila pemidanaan pun gagal menciptakan penaatan, maka cara selanjutnya adalah penghentian sementara usaha/kegiatan. Selanjutnya, apabila cara ini masih gagal maka cara terakhir yang diambil adalah pencabutan izin usaha/kegiatan. Cara penegakan hukum
} 
Menurut Gunningham dan Sinclair, smart regulation setidaknya berbeda dari responsive regulation di dalam dua hal. Pada satu sisi, responsive regulation hanya memfokuskan pada interaksi antara pemerintah sebagai regulator dengan dunia usaha sebagai regulatee, sedangkan smart regulation menunjukkan adanya kebutuhan akan keterlibatan pihak ketiga yaitu masyarakat, baik komersial maupun non-komersial, di dalam penyusunan dan penerapan regulasi. Dengan demikian, maka piramida penegakan hukum yang dikembangkan oleh Ayres dan Braithwaite diubah dari yang sebelumnya berupa piramida dua dimensi menjadi piramida tiga dimensi (limas segitiga), yaitu melibatkan pemerintah, regulatee, dan masyarakat.64 Pada sisi lain, apabila responsive regulation hanya berupaya untuk mencari bentuk respons di dalam satu tipe pendekatan penaatan tertentu, yaitu regulasi (CAC), maka di dalam smart regulation, eskalasi respons tersebut dapat saja melibatkan beberapa tipe pendekatan/instrumen. ${ }^{65}$

Lebih jauh lagi, perlu pula diterangkan di sini bahwa smart regulation menyadari keterbatasan dari eskalasi respons dari piramida penegakan hukum-nya Ayres dan Braithwaite. Menurut Gunningham, piramida tersebut tidak berlaku ketika terdapat kemungkinan kerusakan lingkungan yang katastrofik dan tidak dapat dipulihkan (irreversible).

(penjatuhan sanksi) seperti ini dikatakan responsif karena sanksi akan semakin meningkat (semakin keras dan membebani) seiring dengan meningkatnya pelanggaran. Selain itu, respons penegakan hukum ini juga mengikuti bentuk piramida karena diasumsikan bahwa pelaku usaha/kegiatan yang tidak menaati atau tidak memberikan respons atas sanksi yang diberikan akan semakin menurun jumlahnya seiring dengan meningkatnya tingkat kekerasan sanksi. Lihat: Ian Ayres dan John Braithwaite, Responsive Regulation: Transcending the Deregulation Debate, Oxford: Oxford University Press, hlm. 35-36.

Dalam pandangan Gunningham dan Sinclair, responsive regulation merupakan bentuk regulasi yang dialogis, dalam artian bahwa pemerintah memberikan sinyal kepada dunia usaha tentang tindakan apa yang harus diambil oleh dunia usaha dan kemudian memberikan respons penegakan hukum apabila mereka menunjukkan ketidaktaatan. Respons penegakan hukum ini dimulai dari tingkat yang tidak terlalu intervensionis, dan akan meningkat menuju respons (sanksi) yang semakin berat dan intervensionis manakala dunia usaha gagal melakukan penaatan terhadap regulasi. Karena itu, responsive regulation ditunjukkan dengan adanya eskalasi sanksi di dalam piramid, di mana pada puncak piramid tersebut terdapat sanksi yang apabila digunakan akan cukup untuk menghukum dan memberikan efek jera pada pelanggaran yang paling serius. Lihat: Neil Gunningham dan Darren Sinclair (1996b), Op Cit., hlm. 864-865.

${ }^{64}$ Neil Gunningham dan Darren Sinclair (1996b), Op Cit., hlm. 867.

Untuk partisipasi masyarakat dalam penciptaan norma dan penaatan, lihat misalnya: Janice Gorin, 2005, "Caught Between Action and Inaction: Public Participation Rights in Voluntary Approaches to Environmental Policy", Stanford Environmental Law Journal, Vol. 21

65Neil Gunningham dan Darren Sinclair (1996b), Op Cit., hlm. 866-868.

Senada dengan itu, Holley dan Sinclair menerangkan bahwa smart regulation merupakan perluasan dari responsive regulation dalam dua aspek. Pertama adalah dengan memperluas aktor yang dapat memberikan respons. Dalam hal ini, respons tidak lagi hanya dapat diberikan oleh pemerintah, tetapi juga dapat diberikan oleh pihak kedua (industri) dan pihak ketiga (masyarakt atau LSM). Kedua adalah dengan menggunakan berbagai instrumen penaatan. Dengan kedua aspek ini, keterlibatan banyak aktor dan multimoda instrumen lebih dikehendaki dibandingkan dengan penegakan oleh satu aktor dengan menggunakan satu instrumen. Cameron Holley dan Darren Sinclair, "Enforcement Strategies: Inspection, Targeting, and Escalation”, dalam: LeRoy C. Paddock, David L. Markell, dan Nicholas S. Bryner (eds.), Compliance and Enforcement of Environmental Law (Cheltenham, UK: Edward Elgar, 2017), hlm. 106. Lihat pula diskusi singkat Gunningham mengenai perbedaan responsive regulation dengan smart regulation, dalam: Neil Gunningham (2017), “Compliance, Deterrence, and Beyond”, dalam: LeRoy C. Paddock, David L. Markell, dan Nicholas S. Bryner (eds.), Compliance and Enforcement of Environmental Law (Cheltenham, UK: Edward Elgar, 2017), hlm. 68-71. 
Instrumen Ekonomi, Command and Control, dan Instrumen Lainnya: Kawan atau Lawan?

Pada situasi ini, respons terhadap pelanggaran tidak dapat dilakukan secara bertingkat. Sebaliknya, respons harus dilakukan secara horizontal, yaitu dengan menerapkan beberapa instrumen secara bersamaan. Pada sisi lain, respons yang bereskalasi hanya dapat efektif apabila terdapat interaksi yang berkesinambungan di antara regulator dan regulatee. Artinya, pada saat hanya terdapat sekali saja kesempatan untuk mempengaruhi perilaku regulatee, maka respons yang paling keras dan intervensionis dapat dilakukan, terutama pada saat terdapat risiko munculnya kerusakan yang besar akibat dari pelanggaran. ${ }^{66}$

Lima ciri umum smart regulation dapat dilihat dari uraian Gunningham dan Sinclair berikut ini. Pertama, diterapkannya instrumen yang saling komplementer (mixes), sambil menghindari kehendak "smorgasbordism" yaitu ingin menerapkan semua instrumen. Kedua, diadopsinya "the virtue of parsimony", yaitu mendahulukan penerapan instrumen yang kurang intervensionis. Ketiga, dijalankannya sistem yang responsif terhadap pelanggaran, di mana respons akan bereskalasi sesuai dengan tingkat pelanggaran, dan pada puncaknya terdapat respons yang cukup keras untuk membuat jera pelanggaran yang paling serius. Keempat, didayagunakannya peran negara sebegai regulator, serta industri dan masyarakat sebagai regulator pengganti (subrogate regulators). Kelima, dimaksimalkannya instrumen yang mampu mendorong tercapainya beyond compliance. ${ }^{67}$

Tulisan ini melihat bahwa kombinasi instrumen memegang peranan yang sangat sentral dalam smart regulation. Karena itu, gambaran mengenai kombinasi apa yang baik, dan mana yang harus dihindari, merupakan hal yang sangat penting untuk diperhatikan. Untuk singkatnya, penjelasan berikut ini hanya memaparkan pokok-pokok kombinasi instrumen berdasarkan pembahasan Gunningham et al. dalam Smart Regulation: Designing Environmental Policy. ${ }^{68}$

Kombinasi beberapa instrumen dapat secara inheren bersifat positif atau saling melengkapi (inherently complementary). Kombinasi dianggap secara inheren saling melengkapi apabila efektivitas satu instrumen akan meningkat secara signifikan apabila dikombinasikan dengan instrumen lainnya. Kombinasi yang secara inheren bersifat positif antara lain adalah: Pertama, penerapan kewajiban membuka informasi (mandatory disclosure) dengan instrumen penaatan lainnya; Kedua, penerapan instrumen sukarela dengan CAC (performance standard); Ketiga, penerapan self-regulation dengan CAC; Keempat, penerapan CAC atau self-regulation

66Neil Gunningham (2010), Op Cit., hlm. 134.

67Neil Gunningham dan Darren Sinclair (1996b), Op Cit., hlm. 856.

68Untuk gambaran mendetail tentang kombinasi ini, lihat: Neil Gunningham, Peter Grabosky, dan Darren Sinclair, 2004, Op Cit., hlm. 427-448. Lihat pula: Neil Gunningham and Darren Sinclair (1999a), Op Cit., hlm. 49-76. 
dengan insentif finansial (supply-side incentives); Kelima, penerapan CAC atau self-regulation dengan instrumen ekonomi umum (broad-based economic instruments) yang ditujukan untuk aspek/target yang berbeda; Keenam, penerapan pertanggungjawaban perdata (civil liability) dengan CAC atau self-regulation; dan Ketujuh, penerapan kewajiban pelaporan dan pemantauan dengan instrumen ekonomi umum (broad based economic instruments)

Di samping terdapat kombinasi yang secara inheren bersifat positif, ada pula kombinasi yang akan mencapai hasil positif apabila diterapkan berurutan (sekuensial). Kombinasi positif secara sekuensial tersebut antara lain adalah: Pertama, penerapan self-regulation yang diikuti dengan CAC; dan Kedua, penerapan self-regulation yang dilanjutkan dengan instrumen ekonomi umum.

Tidak selamanya kombinasi instrumen akan menghasilkan efektivitas yang diharapkan. Sebaliknya, beberapa kombinasi secara inheren justru bersifat negatif, yaitu kontra produktif, tidak kompatibel, atau bahkan akan mengurangi efektivitas dari tiap instrumen apabila diterapkan secara mandiri. Beberapa kombinasi yang secara inheren bersifat negatif adalah: Pertama, penerapan CAC dengan instrumen ekonomi umum yang ditujukan pada aspek/target yang sama; Kedua, penerapan self-regulation atau instrumen sukarela dengan instrumen ekonomi; dan Ketiga, penerapan instrumen ekonomi dengan pertanggungjawaban perdata.

Penjelasan tentang kombinasi di atas sekaligus menunjukkan pula pentingnya interaksi antara pemerintah, masyarakat, dan pelaku usaha/kegiatan. Dalam hal ini, CAC dan instrumen ekonomi mengindikasikan adanya peran pemerintah dalam jumlah yang signifikan. Sedangkan self-regulation dan instrumen sukarela mengindikasikan adanya peran pelaku usaha/kegiatan yang sangat besar, sementara peran pemerintah sangat sedikit.

Masyarakat dapat berperan sangat penting bukan hanya sebagai pendorong peningkatan akuntabilitas pemerintah, terutama dalam pelaksanaan CAC, tetapi juga sebagai penentu efektivitas instrumen yang bersifat refleksif. Masyarakat, baik masyarakat korban maupun LSM, juga sangat berperan di dalam pertanggungjawaban perdata, karena mereka lah yang dapat menjadi pihak penggugat di dalam kasus pencemaran lingkungan. Lebih dari itu, keberhasilan instrumen edukasi dan informasi, serta beberapa instrumen sukarela atau selfregulation seperti perjanjian sukarela, label sukarela, dan sertifikasi sukarela, akan sangat tergantung pada bagaimana masyarakat dan konsumen bereaksi terhadap perilaku pelaku usaha/kegiatan. Gunningham dan Sinclair menyebut peran masyarakat ini dapat diwujudkan dalam bentuk "civil regulation and participatory governance" (regulasi non-pemerintah dan tata 
Instrumen Ekonomi, Command and Control, dan Instrumen Lainnya: Kawan atau Lawan?

kelola partisipatoris). Dalam hal ini, masyarakat, konsumen, atau LSM menentukan standar yang perlu diikuti oleh pelaku usaha. Selain itu, berbagai bentuk boykot atau kampanye yang dapat mempengaruhi reputasi pelaku usaha. ${ }^{69}$ Respons masyarakat ini lah, yang oleh Gunningham, Kagan, dan Thornton, dinamakan sebagai "izin” sosial (social license). Dalam hal ini, masyarakat memberikan respons berupa ketidaksetujuan atas kinerja lingkungan perusahaan di dalam berbagai bentuk, misalnya protes, boikot, sampai dengan kampanye negatif. ${ }^{70}$

\section{KESIMPULAN}

$\mathrm{D}$ ikotomi instrumen penaatan lingkungan ke dalam CAC dan instrumen ekonomi merupakan pembagian yang keliru. Pembagian ini pada satu sisi didasarkan pada anggapan bahwa hanya ada instrumen penaatan CAC yang sangat mengandalkan peran pemerintah, dan instrumen ekonomi yang memerlukan peran pemerintah sedikit bahkan tidak ada. Anggapan ini keliru tidak saja karena berdasarkan sejarah perkembangannya instrumen penaatan itu terdiri atas empat tahap (CAC, instrumen ekonomi, instrumen hukum refleksif, serta instrumen integratif dan multimoda), tetapi juga karena hanya instrumen hukum refleksif lah yang tidak memerlukan peran pemerintah terlalu besar. Secara konseptual tidaklah tepat mengelompokkan instrumen refleksif, yang lebih bersifat sukarela, ke dalam instrumen ekonomi.

Pada sisi lain, dikotomi CAC dan instrumen ekonomi juga didasarkan pada anggapan keliru bahwa CAC merupakan pendekatan/instrumen penaatan yang sudah ketinggalan zaman, inferior dibandingkan dengan pendekatan/instrumen lainnya, dan karenanya harus ditinggalkan. Tulisan ini melihat bahwa yang perlu dicari bukanlah satu instrumen terbaik, tetapi berbagai instrumen yang jika dikombinasikan dalam kondisi tertentu akan menghasilkan kebijakan penaatan lingkungan yang optimal.

Dalam perspektif smart regulation, norma, dorongan, atau paksaan atas penaatan tidak lagi hanya dapat diberikan oleh pemerintah sebagai regulator kepada pelaku usaha sebagai pihak yang diatur, melainkan juga dapat diciptakan oleh industri sendiri (dalam bentuk selfregulation), serta oleh pasar dan masyarakat umum. Instrumen penaatan yang cerdas karenanya bersifat terbuka terhadap pluralisme pengaturan.

\footnotetext{
${ }^{69}$ Neil Gunningham dan Darren Sinclair (2002), Op Cit., hlm. 195-197.

70Neil Gunningham, Robert A. Kagan, Dorothy Thornton, 2003, Shades of Green: Business, Regulation, and Environment, California: Stanford University Press, hlm. 36-38.
} 


\section{DAFTAR PUSTAKA}

\section{Buku}

Ayres, Ian dan John Braithwaite. 1992, Responsive Regulation: Transcending the Deregulation Debate. Oxford: Oxford University Press;

Boyd, J. 2003, “A Market-Based Analysis of Financial Insurance Issues Associated with US Natural Resource Damage Liability". Dalam: M. Faure (ed.), Deterrence, Insurability, and Compensation in Environmental Liability: Future Developments in the European Union. Vienna: Springer;

Croci, Edoardo, 2005. "The Economics of Environmental Voluntary Agreements". Dalam: Edoardo Croci (ed.), The Handbook of Environmental Voluntary Agreements: Design, Implementation and Evaluation Issues. Dordrecht: Springer;

Faure, Michael, Marjan Peeters, dan Andri G. Wibisana, 2006, “Economic Instruments: Suited to Developing Countries?". Dalam: Michael Faure dan Nicole Niessen (eds.), Environmental Law in Development: Lessons from the Indonesian Experience. Cheltenham, UK: Edward Elgar;

Faure, Michael G. dan Roy A. Partain, 2019, Environmental Law and Economics: Theory and Practice. Cambridge: Cambridge University Press;

Gunningham, Neil dan Darren Sinclair, 2002, Leaders and Laggards: Next-Generation Environmental Regulation. Sheffield: Greenleaf Publishing Ltd;

Gunningham, Neil, Robert A. Kagan, dan Dorothy Thornton, 2003, Shades of Green: Business, Regulation, and Environment. California: Stanford University Press;

Gunningham, Neil, Peter Grabosky, dan Darren Sinclair, 2004, Smart Regulation: Designing Environmental Policy. Oxford: Oxford University Press;

Gunningham, Neil. “Compliance, Deterrence, and Beyond”, dalam: LeRoy C. Paddock, David L. Markell, dan Nicholas S. Bryner (eds.), 2017, Compliance and Enforcement of Environmental Law. Cheltenham, UK: Edward Elgar;

Heldeweg, Michiel A. dan René J.G.H. Seerden, 2012, Environmental Law in the Netherlands. Alphen aan de Rijn: Wolters Kluwer;

Holley, Cameron dan Darren Sinclair. 2017, “Enforcement Strategies: Inspection, Targeting, and Escalation", dalam: LeRoy C. Paddock, David L. Markell, dan Nicholas S. Bryner (eds.), Compliance and Enforcement of Environmental Law. Cheltenham, UK: Edward Elgar; Hunter, David, James Salzman, dan Durwood Zaelke, 1998, International Environmental Law and Policy. New York: Foundation Press; 
Instrumen Ekonomi, Command and Control, dan Instrumen Lainnya: Kawan atau Lawan?

Iannuzzi Jr., Alphonse., 2002. Industry Self-Regulation and Voluntary Environmental Compliance. Washington, DC: Lewis Publishers;

Mol, Arthur P.J., 2008, Environmental Reform in the Information Age: The Contours of Informational Governance. Cambridge: Cambridge University Press;

Oates, Wallace dan William Baumo, 1996. "Instrument for Environmental Policy". Dalam: Oates, W.E. (ed.). The Economics of Environmental Regulation. Cheltenham: Edward Elgar; OECD, 2003.Voluntary Approaches for Environmental Policy: Effectiveness, Efficiency and Usage in Policy Mixes. Paris: OECD;

Ogus, Anthony. 2004.Regulation: Legal Form and Economic Theory. Oxford: Clarendon Press;

Percival, Robert V., et al.. 2013, Environmental Regulation: Law, Science, and Policy, 7th ed. New York: Wolters Kluwer Law \& Business;

Prakash, Aseem dan Matthew Potoski. The Voluntary Environmentalists: Green Clubs, ISO 14001, and Voluntary Regulations. Cambridge: Cambridge University Press, 2006;

Reliantoro, Sigit., 2012, The Gold for Green: Bagaimana Penghargaan PROPER Emas Mendorong Lima Perusahaan Mencapai Inovasi, Penciptaan Nilai dan Keunggulan Lingkungan. Jakarta: Kementerian Lingkungan Hidup;

Riyanto, Budi, 2005, Hukum Kehutanan dan Sumber Daya Alam: Menuju Smart Regulation. Bogor: Lembaga Pengkajian Hukum Kehutanan dan Lingkungan;

Santosa, Mas Achmad, 2001, Good Governance dan Hukum Lingkungan. Jakarta: ICEL;

Soemarwoto, Otto. Atur Diri Sendiri: Paradigma Baru Pengelolaan Lingkungan Hidup. Pembangunan Ramah Lingkungan: Berpihak pada Rakyat, Ekonomis, dan Berkelanjutan. Yogyakarta: Gajah Mada University Press, 2001;

Sullivan, Rory, 2005, Rethinking Voluntary Approaches in Environmental Policy. Cheltenham, UK: Edward Elgar;

Turner, R. Kerry, David Pearce, dan Ian Bateman. 1994, Environmental Economics: An Elementary Introduction. New York: Harvester Wheatsheaf;

Wilkinson, David. 2002, Environment and Law. New York: Routledge;

Wurzel, Rüdiger, Anthony Zito, dan Andrew Jordan, 2019, “Smart (and Not-So-Smart) Mixes of New Environmental Policy Instruments". Dalam: Judith van Erp, et al., Smart Mixes for Transboundary Environmental Harm. Cambridge: Cambridge University Press. 


\section{Jurnal}

Arnold, Craig Anthony, Spring 2011, “Fourth-Generation Environmental Law: Integrationist and Multimodal". William \& Mary Environmental Law and Policy Review, Vol. 35:3;

Beattie, Karen, 2000-2001, "Fairness, Openness and Self-Regulation: An Examination of Administrative Law Values and the Use of Voluntary and Self-Regulatory Measures for Environmental Protection". Canadian Journal of Administrative Law E Practice, Vol. 14;

Case, David W, Fall 2006, “Changing Corporate Behavior through Environmental Management Systems". William and Mary Environmental Law and Policy Review, Vol. 31;

Cheng, Linlin dan Jeffrey G. Skousen, 2017, “Comparison of International Mine Reclamation Bonding Systems with Recommendations for China". International Journal of Coal Science E Technology, Vol. 4:2;

Costanza, Robert dan Charles Perrings, 1990, “A Flexible Assurance Bonding System for Improved Environmental Management". Ecological Economics, Vol. 2;

Costanza, Robert dan Laura Cornwell, 1992, “The 4P Approach to Dealing with Scientific Uncertainty". Environment, Vol. 34:9;

Gorin, Janice, January 2005, “Caught Between Action and Inaction: Public Participation Rights in Voluntary Approaches to Environmental Policy". Stanford Environmental Law Journal, Vol. 21;

Goulder, Lawrence H. dan Ian W. H. Parry, Summer 2008, “Instrument Choice in Environmental Policy". Review of Environmental Economics and Policy, Vol. 2;

Gunningham, Neil, sep 2010, “Enforcement and Compliance Strategies". Dalam: Robert Baldwin, Martin Cave, and Martin Lodge (eds.). The Oxford Handbook of Regulation, DOI:10.1093/oxfordhb/9780199560219.003.0007;

Gunningham, Neil dan Cameron Holley, 2016, "Next-Generation Environmental Regulation: Law, Regulation, and Governance". Annual Review of Law and Social Science, Vol. 12; Gunningham, Neil dan Darren Sinclair, January 1999, “Regulatory Pluralism: Designing Policy Mixes for Environmental Protection". Law \& Policy, Vol. 21: 1;

Gunningham, Neil dan Darren Sinclair, 1999, “Integrative Regulation: A Principle-Based Approach to Environmental Policy". Law and Social Inquiry, Vol. 24;

Hardin, Garret, 1968, "The Tragedy of the Commons". Science, Vol. 162;

Kerret, Dorit dan Alon Tal, Fall, 2005, "Greenwash or Green Gain? Predicting the Success and Evaluating the Effectiveness of Environmental Voluntary Agreements". Penn State Environmental Law Review, Vol. 14; 
Instrumen Ekonomi, Command and Control, dan Instrumen Lainnya: Kawan atau Lawan?

Nel, J.G. dan J.A. Wessels, (2010), “How to Use Voluntary, Self-Regulatory and Alternative Environmental Compliance Tools: Some Lessons Learnt". Potchefstroom Electronic Law Journal, Vol. 13;

Ogus, Anthony. 1999, "Nudging and Rectifying: the Use of Fiscal Instruments for Regulatory Purposes". Legal Studies, Vol. 19;

Orts, Eric W, 1995a, "A Reflexive Model of Environmental Regulation". Business Ethics Quarterly, Vol. 5:4 ;

Orts, Eric W, 1995,“Reflexive Environmental Law”. Northwestern University Law Review, Vol. 89;

Patterson III, Charles D, (2000),"Environmental Taxes and Subsidies: What is the Appropriate Fiscal Policy for Dealing with Modern Environmental Problems?". William \& Mary Environmental Law and Policy Review, Vol. 24:1;

Stewart, Richard B, 2001, “A New Generation of Environmental Regulation?”. Capital University Law Review, Vol. 29;

Taylor, C., S. Pollard, S. Rocks, dan A. Angus, 2012, “Selecting Policy Instruments for Better Environmental Regulation: a Critique and Future Research Agenda". Environmental Policy and Governance, Vol. 22:4 ;

Wibisana, Andri G. (2017), “Campur Tangan Pemerintah dalam Pengelolaan Lingkungan: Sebuah Penelusuran Teoretis Berdasarkan Analisis Ekonomi atas Hukum (Economic Analysis of Law)". Jurnal Hukum \& Pembangunan, Vol. 47:2;

\section{Sumber Lain}

Walls, Margaret. "Deposit-Refund Systems in Practice and Theory", RFF Discussion Paper, November 2011 RFF DP 11-47, terserdia pada: <https://media.rff.org/ documents/RFFDP-11-47.pdf>. 